\title{
Simulating the impacts of climate change on cotton production in the Mississippi Delta
}

\author{
K. Raja Reddy ${ }^{1, *}$, Prashant R. Doma ${ }^{1}$, Linda O. Mearns ${ }^{2}$, Mariquita Y. L. Boone ${ }^{1}$, \\ Harry F. Hodges ${ }^{1}$, Alec G. Richardson ${ }^{1}$, Vijaya Gopal Kakani ${ }^{1}$ \\ ${ }^{1}$ Department of Plant and Soil Sciences, Box 9555, Mississippi State University, Mississippi State, Mississippi 39762, USA \\ ${ }^{2}$ National Center for Atmospheric Research, Environmental and Societal Impacts, NCAR, PO Box 3000, Boulder, \\ Colorado 80307, USA
}

\begin{abstract}
General circulation models (GCMs) project increases of the earth's surface air temperatures and other climate changes in the middle or latter part of the 21st century, and therefore crops such as cotton (Gossypium hirsutum L.) will be grown in a much different environment than today. To understand the implications of climate change on cotton production in the Mississippi Delta, 30 years (1964 to1993) of cotton growth and yield at Stoneville, Mississippi, USA, were simulated using the cotton simulation model GOSSYM. The GCM projections showed a nearly $4^{\circ} \mathrm{C}$ rise in average temperature and a decrease in precipitation during the crop growing season. The fertilization effect of an increase in atmospheric $\mathrm{CO}_{2}$ concentrations from 360 to $540 \mathrm{ppm}$, without the change in other climatic variables, increased yields by $10 \%$ from 1563 to $1713 \mathrm{~kg} \mathrm{ha}^{-1}$, but when all projected climatic changes were included, yields decreased by $9 \%$ from 1563 to $1429 \mathrm{~kg} \mathrm{ha}^{-1}$. The rate of plant growth and development was higher in the future because of enhanced metabolic rates at higher temperatures combined with increased carbon availability. The effect of climate change on cotton production was more drastic in a hot and dry year. Since most of the days with average temperatures above $32^{\circ} \mathrm{C}$ will likely occur during the reproductive phase, irrigation will be needed to satisfy the high water demand, and this reduces boll abscission by lowering canopy temperatures. Therefore, if global warming occurs as projected, fiber production in the future environment will be reduced, and breeding heat-cold-tolerant cultivars will be necessary to sustain cotton production in the US mid-South. Cultural practices such as earlier planting may be used to avoid the flowering of cotton in the high temperatures that occur during mid to late summer.
\end{abstract}

KEY WORDS: Cotton - Climate change $\cdot$ Simulation modeling $\cdot$ Global warming $\cdot$ Temperature Carbon dioxide $\cdot$ GCM

\section{INTRODUCTION}

Climate change has been occurring on diverse scales of space and time and is the normal state of affairs for the climate-atmosphere system (Mearns 2000). Activities related to energy use and land use changes have grown substantially during the last century and have contributed to 'anthropogenic' climate change. The concentration of carbon dioxide $\left(\left[\mathrm{CO}_{2}\right]\right)$ in the atmo-

*E-mail: krreddy@ra.msstate.edu sphere has increased by more than $28 \%$ since the beginning of the Industrial Revolution, mainly because of the burning of fossil fuels, as well as deforestation (Reicosky et al. 2000, Houghton et al. 2001). The most recent future scenarios of greenhouse gases in the atmosphere indicate that $\left[\mathrm{CO}_{2}\right]$ could increase from current levels of $360 \mathrm{ppm}$ to between 540 and $970 \mathrm{ppm}$ by the end of the 21st century (Houghton et al. 2001). General circulation models (GCMs) project that the global temperature increase would range from 1.4 to $5.8^{\circ} \mathrm{C}$ because of projected increases in the concentra- 
tions of all greenhouse gases by the end of the 21st century. Climatic patterns within any region will become more variable and are difficult to determine, but the rate of future warming over the United States is expected to be faster than the mean global rate with more frequent occurrence of extremely hot years (Houghton et al. 2001). The projections for future regional precipitation patterns are even more variable and difficult to predict.

The plant processes directly affected by changes in atmospheric $\left[\mathrm{CO}_{2}\right]$ are mainly photosynthesis, photorespiration, dark respiration, and transpiration (Fitter \& Hay 1987). Elevated $\left[\mathrm{CO}_{2}\right]$ generally enhances leaf and canopy photosynthesis because of increased concentrations of ribulose-1,5-bisphosphate carboxylase/ oxygenase (Rubisco) and suppression of photorespiration in $\mathrm{C}_{3}$ plants such as cotton (Reddy et al. 2000). In addition, higher atmospheric $\left[\mathrm{CO}_{2}\right]$ results in the partial closure of stomata (Morison 1987), thus reducing leaf-level transpiration and indirectly increasing tissue temperature. A reduction in transpiration of at least $30 \%$ has been reported for plants grown in atmospheres with doubled $\left[\mathrm{CO}_{2}\right]$ (Kimball \& Idso 1983, Rosenzweig \& Hillel 1998). This potential decrease in transpiration with increased photosynthesis leads to increased water use efficiency under elevated $\left[\mathrm{CO}_{2}\right]$ conditions (Reddy et al. 2000). Kimball (1983), in his analysis of 430 reports dealing with plant responses to elevated $\left[\mathrm{CO}_{2}\right]$ found that, on average, doubling of atmospheric $\left[\mathrm{CO}_{2}\right]$ would cause a $33 \%$ increase in yield in $\mathrm{C}_{3}$ crops. Although growth rates are sensitive to elevated $\left[\mathrm{CO}_{2}\right]$, major cotton phenological events, emergence to reproductive initiation, the square period and the boll maturation period, are not affected by $\left[\mathrm{CO}_{2}\right]$ (Reddy et al. 1996, 1997a,b).

Cotton grows at temperatures ranging from a minimum of 12 to $15^{\circ} \mathrm{C}$ to an optimum of 26 to $28^{\circ} \mathrm{C}$, and the maximum plant-sustainable temperature depends on the duration of exposure (Reddy et al. 1997b). The most sensitive yield-related period for high temperatures is a short period prior to, during and immediately after flowering. Fruit production efficiency in cotton increases with temperatures up to $29^{\circ} \mathrm{C}$ and then declines sharply with higher temperatures, probably because net photosynthesis is less at both higher and lower temperatures than at optimum (Reddy et al. 2000). Cotton plants produce bolls until the available photosynthates can no longer support additional fruit. After photosynthate requirements are met because of fruit maturation or abscission, vegetative growth resumes. High-temperature grown plants (above $32^{\circ} \mathrm{C}$ ) show luxuriant vegetative growth due to premature boll abscission (Reddy et al. 1997b,c). High temperatures also cause hastening of development especially during the boll-filling period, thus resulting in smaller bolls, lower yields and poor lint quality (Hodges et al. 1993, Reddy et al. 1999).

As air temperature increases from 26 to $36^{\circ} \mathrm{C}$, transpiration rates increase linearly (Reddy et al. 1998a). In experimental settings, Reddy et al. $(1997 \mathrm{~b}, \mathrm{c})$ observed increased photosynthesis due to doubled $\left[\mathrm{CO}_{2}\right]$ under a range of water and nutrient stress conditions. Doubled ambient $\left[\mathrm{CO}_{2}\right]$ cause about a $40 \%$ increase in vegetative dry matter accumulation across a wide range of temperatures (Reddy et al. 2000).

Crop responses to the environment, however, vary from region to region based on soil type, plant type and regional weather. The projected higher temperatures would be favorable to the colder parts of the world because of a longer growing season. However, higher temperatures might result in hastened development and reduced yields in the warmer regions, particularly during the critical crop growth periods in summer (Rosenzweig \& Hillel 1998). The impacts of climate change on crop production, i.e. the probability, frequency and severity of extreme conditions, are important to society (Rosenzweig \& Parry 1994, Houghton et al. 1996, Rosenzweig \& Iglesias 1998, Reilly \& Schimmelpfennig 1999).

Crop simulation models in combination with GCMs or other climate scenarios have been used for predicting future crop production (Rosenzweig \& Iglesias 1998, Reilly \& Schimmelpfennig 1999). Relative changes predicted by GCMs have served as the basis for future weather information (Rosenzweig \& Hillel 1998). Temperature is the most important weather variable forecast to change due to anthropogenic causes, but precipitation and the interaction of weather and soils are also important determinants of agricultural productivity. A high level of uncertainty concerning the effects of climate change on crop processes and yield exists, partly because of lack of information required to understand crop responses to global warming, and to develop realistic physiologically robust crop simulation models.

The objective of this study is to assess the impact of climate change and elevated $\left[\mathrm{CO}_{2}\right]$ on cotton production in Stoneville, Mississippi. Specifically, the model was used to study the relationships among cotton production and (1) carbon dioxide enrichment, (2) specific weather parameter changes, and (3) climatic extremes.

\section{MATERIALS AND METHODS}

2.1. The Cotton Simulation Model GOSSYM. Cotton, the fifth most economically important crop in the world, is grown on more than 5 Mha in the USA, and over 34 Mha worldwide (USDA 1998, Reddy et al. 2000). Most of the world's production is in arid and 
semiarid climates. Cotton, being indeterminate in growth habit, responds fairly well to changes in environment and management (Reddy et al. 1997b, Gerik et al. 1998). Nearly 15 different cotton development models have been proposed and published (Jallas 1998). Of these, the GOSSYM model is the most mechanistic and has been used in commercial agriculture to aid in crop management decisions. The model development, algorithms and applications have been described (Baker et al. 1983, McKinion et al. 1989, Boone et al. 1995, Reddy et al. 1997d, 2002, Hodges et al. 1998).

GOSSYM continues to evolve as new concepts or better ways of dealing with existing concepts become available. Recent enhancements include new stem and leaf elongation routines (Reddy et al. 1997d), and a fruit production efficiency function to simulate boll abscission at high temperatures (Reddy et al. 1997a). Since GOSSYM estimates photosynthesis and ET at the canopy level, the $\mathrm{CO}_{2}$ dependence of stomatal closure is not parameterized in GOSSYM, because Reddy et al. (2000) have shown that canopy-level transpiration is relatively insensitive to changes in $\mathrm{CO}_{2}$. Apparently the enhanced leaf area effect approximately offsets the stomatal closure effect as $\mathrm{CO}_{2}$ is increased: while transpiration per unit leaf area decreases, total transpiration integrated over the total leaf area remains relatively constant.

GOSSYM is a mechanistic crop model that includes plant responses to weather and soil. The relationship between weather and soil determines plant water status, which in turn influences plant response to the environment. It responds to water deficits by decreasing leaf turgor, which slows leaf and stem growth and in turn allows more photosynthates to be allocated to the roots. The model responds to higher atmospheric $\mathrm{CO}_{2}$ concentration by increasing photosynthesis. The additional carbohydrates are distributed to their various functions according to plant respiration and growth needs.

Environmental inputs required to run GOSSYM include daily solar radiation, maximum and minimum air temperatures, rainfall, wind speed, and irrigation. Other necessary inputs include the latitude of the site, crop emergence date, date for start and end of season, row spacing, number of plants per row foot, initial soil nitrogen fertility level, and information on the physical and hydraulic properties of the soil. Also required are the date, amount and method of application of irrigation, fertilizer, and plant growth regulators (Hodges et al. 1998).

The model predicts growth and development of the plant, providing daily values for most of the physiological parameters that can be readily measured. It also generates plant maps showing the main stem and branch nodes, and the fruiting sites. As crop maturity progresses, the model estimates nitrogen concentration in different organs of the plant, nitrogen and water status of the soil, and lint yield.

Both iterative and heuristic (i.e. genetic algorithm) approaches have been used to calibrate the model (Boone et al. 1993, Sequeira et. al. 1994). The model has been validated using datasets obtained from farmer-cooperators and experimentation stations across the Cottonbelt (V. R. Reddy et al. 1985, K. R. Reddy et al. 1995, Khorsandi et al. 1997, Reddy \& Boone 2002). A more detailed description of the validation and application effort has been reviewed by Reddy et al. (2002). Although GOSSYM includes the effects of extreme temperatures and of water and nutrient stresses on many physiological processes and yield, the model is far from complete. Factors or limitations of the model concern nutrients other than carbon and nitrogen, as well as damages caused by herbicides, pests, and extreme weather events such as hail and high winds.

2.2. Weather data collection and climate change scenarios. The daily long-term weather data for Stoneville, Mississippi, USA $\left(33.2526^{\circ} \mathrm{N}, 90.5454^{\circ} \mathrm{W}\right)$ reported by Boykin et al. (1995) were used in this study. The actual daily solar radiation, maximum and minimum air temperatures, rainfall, and wind speed for 30 years (1964 to 1993) were used as current or ambient weather input scenarios for the model. Changes in climate were calculated from results of a regional climate model (RegCM) nested within a GCM. The technique of nesting higher resolution RegCMs within GCMs has evolved to increase the spatial resolution of the models within a specific region (Giorgi \& Mearns 1991, McGregor 1997, Mearns 2000). The RegCM (Giorgi et al. 1993a,b) was nested within 5 $\mathrm{yr}$ of the control and doubled $\mathrm{CO}_{2}$ runs of the CSIRO Mk 2 GCM (Watterson 1998, Watterson et al. 1999) over the SE US. The spatial resolutions of the GCM and RegCM are about 5 and $0.5^{\circ}$, respectively. The control run of the RegCM reproduced quite well the climatology of the lower Mississippi sub-region. Biases in temperature on a monthly basis were between 1 and $2^{\circ} \mathrm{C}$, and biases in precipitation were around $-20 \%$ in spring and $+40 \%$ in summer. These values are typical for regional climate modeling experiments. On the whole, the RegCM improved the simulation of the regional climate over the CSIRO GCM (Mearns et al. 2002).

The quantified changes in the future climate (i.e. maximum/minimum temperatures, solar radiation, precipitation, wind speed) were predicted using the RegCM. The projected monthly means of future weather parameters (changes for maximum and minimum temperatures, ratios for precipitation, radiation 
and wind speed) for Mississippi, with double the preindustrial atmospheric $\left[\mathrm{CO}_{2}\right](540 \mathrm{ppm})$, are provided in Table 1.

2.3. Creation of future weather files. The weather input required to run GOSSYM is on a daily basis. The projected monthly means for future weather parameters were used to create daily future weather files by modifying the daily current weather based on the assumption that changes in daily weather parameters will be constant for each month. The monthly mean maximum and minimum temperature changes were added to and the ratios for the other 3 parameters (precipitation, solar radiation and wind speed) were multiplied with the corresponding values of the daily 30-year current weather parameters to generate the daily future weather files for 30 years (future climate scenario). This methodology retains the existing natural variability in the historic weather for the 30 years. It would be more realistic, however, to have access to

Table 1. Future weather parameters for Stoneville, MS, at double the pre-industrial atmospheric carbon dioxide concentrations. Monthly projections of a regionalized global circulation model (RegGCM) by the National Center for Atmospheric Research. Ratios are multiplicative factors for the current weather

\begin{tabular}{|lccccc|}
\hline Month & \multicolumn{2}{c}{$\begin{array}{l}\text { Temperature } \\
\text { increment }\left({ }^{\circ} \mathrm{C}\right)\end{array}$} & $\begin{array}{c}\text { Precipitation } \\
\text { (ratio) }\end{array}$ & $\begin{array}{c}\text { Solar } \\
\text { radiation } \\
\text { (ratio) }\end{array}$ & $\begin{array}{c}\text { Wind } \\
\text { speed } \\
\text { (ratio) }\end{array}$ \\
\hline January & Min. & & 0.74 & 0.98 & 0.94 \\
February & 2.15 & 3.22 & 0.79 & 0.95 & 1.01 \\
March & 5.06 & 5.52 & 2.07 & 0.96 & 0.99 \\
April & 5.31 & 6.99 & 1.63 & 0.95 & 0.87 \\
May & 4.86 & 6.26 & 1.19 & 0.99 & 0.81 \\
June & 3.30 & 3.77 & 1.05 & 1.04 & 0.86 \\
July & 5.59 & 4.63 & 0.75 & 1.06 & 1.08 \\
August & 5.47 & 4.48 & 0.96 & 1.02 & 1.04 \\
September & 4.98 & 4.22 & 0.84 & 1.03 & 0.93 \\
October & 5.31 & 4.91 & 1.19 & 1.05 & 0.99 \\
November & 3.17 & 2.61 & 0.86 & 1.13 & 0.98 \\
December & 5.55 & 4.83 & 0.34 & 1.02 & 0.90 \\
\hline
\end{tabular}

Table 2. Climate change scenarios used in the GOSSYM model for this study, based on the assumption that changes in daily weather parameters will be constant for each month

\begin{tabular}{|ll|}
\hline Scenario & Description \\
\hline 1. Current climate & Actual data for 1964-1993 \\
2. TMAX & Modification of maximum temperatures only \\
3. TMIN & Modification of minimum temperatures only \\
4. TEMP & Modification of maximum and minimum temperatures \\
5. PPT & Modification of the precipitation pattern \\
6. TPPT & Modification of maximum and minimum temperatures \\
7. FUT & and precipitation pattern \\
& Modification of maximum and minimum temperatures, \\
& precipitation pattern, solar radiation, and wind speed \\
\hline
\end{tabular}

both future day-to-day variability and resulting change in interactions among climatic factors. Increased variability in either temperature or rain would definitely alter crop growth and development, because crop yield is often limited by short-term extreme weather events.

A series of future climate scenarios was created (Table 2). The historical weather data from 1964 to 1993 were taken as the current climate scenario. In the modified scenarios, various weather parameters were ied to reflect the future weather.

2.4. Simulations. Various simulations were run to erstand the effects of climate change on cotton for these simulations was Bosket sandy loam, and this region. All simulations were conducted for rain-fed crops with $96.5 \mathrm{~cm}$ row spacing and 10 plants $\mathrm{m}^{-1}$. To avoid nitrogen stress $202 \mathrm{~kg} \mathrm{ha}^{-1}$ of nitrogen fertilizer was applied. The current atmospheric carbon dioxide concentration is assumed as 360 ppm (Keeling \& Whorf 1994). All simulations were conducted under rain-fed (zero-irrigation) conditions. Management practices were assumed to be optimal with no effects of weeds, insects or disease pests. The results are presented as means of 30-year simulations.

\subsection{Carbon dioxide enrichment.}

The response of cotton to enrichment of atmospheric $\left[\mathrm{CO}_{2}\right]$ for each 100 ppm was simulated from 200 ppm to $900 \mathrm{ppm}$, to cover pre-industrial, present, and future atmospheric $\mathrm{CO}_{2}$ levels. These simulations illustrate $\mathrm{CO}_{2}$-fertilization effects on cotton growth and yield.

2.6. Climate change scenarios. Several climate change scenarios were simulated to estimate cotton production. All the future weather scenarios (Table 2) were used as weather inputs for GOSSYM, with atmospheric $\left[\mathrm{CO}_{2}\right]$ held constant at $540 \mathrm{ppm}$. These components of climate change were simulated, ceteris paribus, to isolate their relative contributions and importance to the overall composite climate change effect on cotton growth and yield. The impact of the composite climate change was mainly studied for the future climate scenario (FUT) with elevated $\left[\mathrm{CO}_{2}\right]$ and compared with the current climate scenario at ambient $\left[\mathrm{CO}_{2}\right]$. 
Table 3. General input data for the GOSSYM model for this study

\begin{tabular}{|c|c|}
\hline Location & Stoneville, $\mathrm{MS}\left(33^{\circ} \mathrm{N}\right.$ latitude) \\
\hline Weather data & 30 years (1964-1993) \\
\hline Crop variety & Upland mid-season \\
\hline Soil type & $\begin{array}{l}\text { Bosket fine loamy, mixed, } \\
\text { thermic Mollic Hapludalfs }\end{array}$ \\
\hline Standard growing period & 1 May to 31 October (183 d) \\
\hline Fertilizer application & $\begin{array}{l}\text { Single pre-plant application } \\
\text { of } 202 \mathrm{~kg} \mathrm{ha}^{-1} \text { nitrogen }\end{array}$ \\
\hline Row spacing & $96.5 \mathrm{~cm}$ (38 in.) \\
\hline Plant density & 101894 plants ha ${ }^{-1}$ \\
\hline Current climate scenario & $\begin{array}{l}\text { Ambient } \mathrm{CO}_{2} \text { level }(360 \mathrm{ppm}) \\
\text { with current weather data }\end{array}$ \\
\hline Future climate scenario & $\begin{array}{l}\text { Elevated }\left[\mathrm{CO}_{2}\right](540 \mathrm{ppm}) \\
\text { with future weather data (FUT) }\end{array}$ \\
\hline
\end{tabular}

Based on the 15 to $32^{\circ} \mathrm{C}$ growing temperature range for cotton, an average year in the future will have a longer cotton-growing season (from the beginning of March through early December; Fig. 2). Hence, changing the planting dates seems to be a viable option to mitigate any adverse effects of climate on crop growth. However, high temperatures would result in more rapid metabolism and faster development, and very high temperatures cause boll abscission (Reddy et al. 2000).

Days with average temperatures above $32^{\circ} \mathrm{C}$ occur mostly during the flowering and boll-filling period (Days 160 to 200; Fig. 2), a critical period for stresses to occur. Irrigation under projected decreased precipitation (Table 1) would help satisfy the high water demand or alleviate the high water stress during the reproductive phase and increase boll retention by lowering canopy temperatures. It may also affect the weed and insect population, but these issues were not addressed in this study.
2.7. Climatic extremes. To account for the occurrence of extremes in climate, especially the temperatures, some of the years selected were based on average daily temperatures during the growing season. Based on seasonal temperatures from May 1 to October 31, 1980 (labeled 'hot/dry') was one of the hottest of the 30 years $\left(1.2^{\circ} \mathrm{C}\right.$ higher daily mean temperatures than the 30-yr seasonal average; Fig. 1) and had less rainfall (8.4 cm less than the $30 \mathrm{yr}$ mean) while 1993 was designated as 'hot/wet' (daily mean temperature was $1.2^{\circ} \mathrm{C}$ higher, and rainfall was $5.0 \mathrm{~cm}$ higher than the mean). The year 1984 was selected as the 'cold/dry' year $\left(1^{\circ} \mathrm{C}\right.$ lower daily mean temperature and $2.7 \mathrm{~cm}$ lower total seasonal rainfall), while 1989 was a 'cold/wet' year $\left(1.3^{\circ} \mathrm{C}\right.$ lower daily mean temperature and $41.0 \mathrm{~cm}$ higher seasonal precipitation). The year 1992 was classified as a 'normal' year with no significant extremes in temperature or precipitation compared to the 30-yr means.

\section{RESULTS AND DISCUSSION}

The change projected for future climate in the Mississippi Delta region showed nearly a $4^{\circ} \mathrm{C}$ rise in the average temperatures for the crop growing season, a projected decrease in precipitation, particularly during the flowering period, and minor variations in solar radiation and wind speed (Table 1). The rise in temperatures is associated with more extreme precipitation and faster evaporation of water, leading to greater frequency of both very wet and very dry conditions.

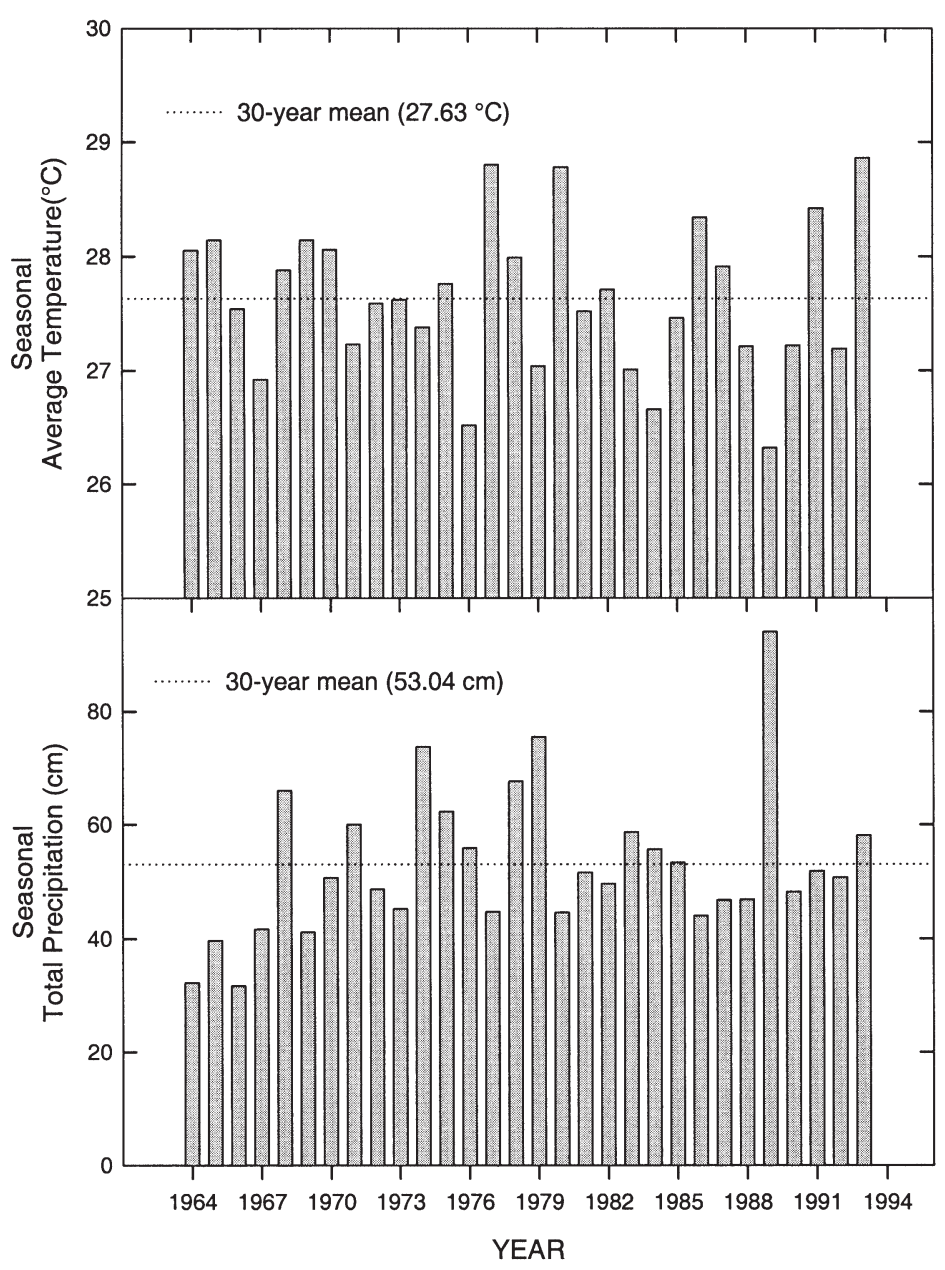

Fig. 1. Temperatures and precipitation for 30 years during the growing season (1 May to 31 October) at Stoneville, MS, USA 


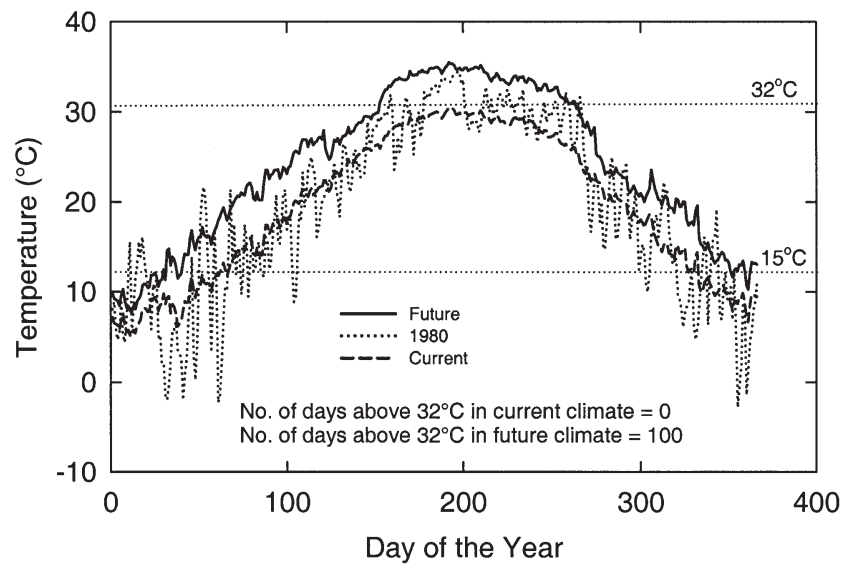

Fig. 2. Average daily 30-yr mean temperatures at Stoneville, MS, for the current and future climate scenarios, and daily mean temperatures for 1980 . Horizontal dotted lines: lower limit for cotton growth $\left(15^{\circ} \mathrm{C}\right)$, and upper limit for cotton fruit retention $\left(32^{\circ} \mathrm{C}\right)$

\subsection{Carbon dioxide fertilization effect}

Results from the 30-yr simulations projected higher yields with increased atmospheric carbon dioxide. There was a $60 \%$ increase in yield as $\left[\mathrm{CO}_{2}\right]$ increased from 200 to 900 ppm (Fig. 3). Beneficial $\mathrm{CO}_{2}$ enrichment effects on cotton production were also observed in free-air $\mathrm{CO}_{2}$ enrichment studies, in which cotton grown in ambient $\mathrm{CO}_{2}$ and $\mathrm{CO}_{2}$ enriched to about 540 ppm were compared with $\mathrm{CO}_{2}$ enrichment stimulating a 35 to $60 \%$ increase in yield (Kimball \& Mauney 1993, Mauney et al. 1994, Pinter et al. 1996). The increase in atmospheric $\left[\mathrm{CO}_{2}\right]$ resulted in a mere $10 \%$ increase in simulated cotton lint yields, from 1563 to

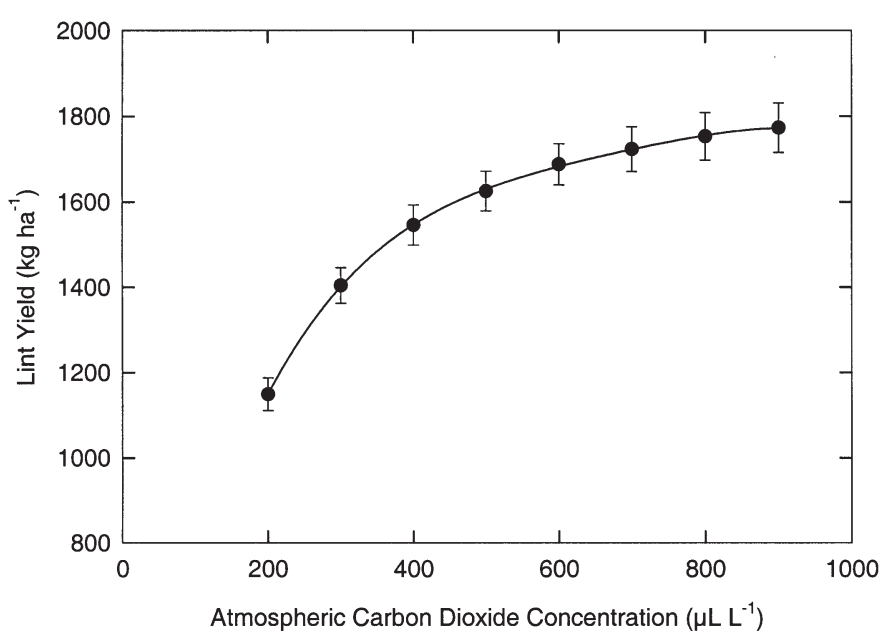

Fig. 3. Simulated cotton lint yield response to enrichment of atmospheric $\left[\mathrm{CO}_{2}\right]$ (30-yr simulations, means $\left.\pm \mathrm{SE}\right)$
$1713 \mathrm{~kg} \mathrm{ha}^{-1}$ (Table 4), illustrating that most of the effects of increased $\left[\mathrm{CO}_{2}\right]$ on cotton may have already occurred. The trends were similar under various extreme climatic conditions. Increased $\left[\mathrm{CO}_{2}\right]$ did not change the directional effects of other environmental factors on cotton yields. Pinter et al. (1996) and Reddy et al. (2000) observed similar beneficial effects of increased $\left[\mathrm{CO}_{2}\right]$ on crop response under drought and high temperature stress conditions. Crop response to increased $\left[\mathrm{CO}_{2}\right]$ was similar, because crops grown in high $\mathrm{CO}_{2}$ environments have higher photosynthetic rates and are thus generally healthier and able to perform better in stress environments compared to crops grown in ambient $\mathrm{CO}_{2}$ environments.

$\mathrm{CO}_{2}$ was found to have no effect on the major phenological events such as the occurrence of first square, first flower, and first open boll. This is because the various developmental rate processes are not parameterized as functions of $\mathrm{CO}_{2}$ in GOSSYM. Based on a series of studies using soil-plant-atmosphere-research units, open-top chambers and free-air $\mathrm{CO}_{2}$ experimental techniques and facilities, Reddy et al. (2000) stated that atmospheric $\mathrm{CO}_{2}$ enrichment did not have any effect on cotton phenology.

\subsection{Climate change scenarios}

Projected future climate change reduced cotton production in the Mississippi Delta. Simulation of cotton production for the various 30-year climate change scenarios showed that elevated $\left[\mathrm{CO}_{2}\right](540 \mathrm{ppm})$ by itself enhanced cotton yield by an average of $12 \%$ (Table 4). However, this beneficial effect of $\mathrm{CO}_{2}$ was always reduced and sometimes negated by accompanying changes in other climate variables. For the 'current', TMAX and PPT weather scenarios, $\mathrm{CO}_{2}$ enrichment resulted in a $10 \%$ increase in yield, showing that the beneficial $\mathrm{CO}_{2}$ effect more than offsets the adverse effect of the TMAX and PPT components of climate change, resulting in a net increase in yield of about $3.5 \%$, from 1563 to 1617 or $1626 \mathrm{~kg}$ ha $^{-1}$ (Table 4). Modeled cotton yield decreased by $6 \%$ in both ambient and elevated $\left[\mathrm{CO}_{2}\right]$ environments under TMAX. Under PPT, a 5\% decrease in lint yield was simulated. Further yield decreases were simulated when both temperature and precipitation were modified (TPPT, Table 4). When all weather parameters were modified (FUT), a $21 \%$ decrease in yield was predicted at ambient $\left[\mathrm{CO}_{2}\right] \mathrm{lev}$ els, and a $17 \%$ yield decrease at elevated $\left[\mathrm{CO}_{2}\right]$ levels. For the FUT scenario, $\mathrm{CO}_{2}$ enrichment resulted in a $16 \%$ increase in predicted yield, compared to a $10 \%$ increase in yield for the current scenario. Climate change thus enhanced the $\mathrm{CO}_{2}$-enrichment 
Table 4. Simulated 30-year average lint yields under various climate change scenarios at ambient and elevated $\mathrm{CO}_{2}$ concentrations for Stoneville, Mississippi, USA (percent change from yield under the current 1964-1993 scenario in parentheses). See Table 2 for abbreviations

\begin{tabular}{|lcccc|}
\hline $\begin{array}{l}\text { Weather } \\
\text { scenarios }\end{array}$ & $\begin{array}{c}\text { Lint yield }\left(\mathrm{kg} \mathrm{ha}^{-1}\right) \\
560 \mathrm{ppm} \\
\mathrm{CO}_{2}\end{array}$ & $\begin{array}{c}540 \mathrm{ppm} \\
\mathrm{CO}_{2}\end{array}$ & $\begin{array}{c}\mathrm{CO}_{2} \text { effect } \\
(\%)\end{array}$ & $\begin{array}{c}\mathrm{CO}_{2}+ \\
\text { weather } \\
\text { effect (\%) }\end{array}$ \\
\hline Current & 1563 & 1713 & 10 & 10 \\
TMAX & $1474(-6)$ & $1617(-6)$ & 10 & 3 \\
TMIN & $1511(-3)$ & $1636(-4)$ & 8 & 5 \\
TEMP & $1325(-15)$ & $1529(-11)$ & 15 & -2 \\
PPT & $1485(-5)$ & $1626(-5)$ & 10 & 4 \\
TPPT & $1309(-16)$ & $1465(-14)$ & 12 & -6 \\
FUT & $1235(-21)$ & $1429(-17)$ & 16 & -9 \\
\hline
\end{tabular}

was projected to increase by $12 \%$ in Kerala, India, with the adverse increased-temperature effect contributing a $6 \%$ yield decline (Sasseendran et al. 2000). Tubiello et al. (2000), in their simulation studies of 6 different crops in several rotation systems in Modena and Foggia, Italy, reported a general decrease in crop yield due to the combined effects of elevated atmospheric $\mathrm{CO}_{2}$ and climate change, with higher temperatures contributing a 10 to $40 \%$ decline, while adaptive management strategies (increased irrigation, earlier planting, slower-maturing cultivars) maintained yield at the current levels.

effect. The net consequence of climate change plus $\mathrm{CO}_{2}$-enrichment was a decrease in yield of $9 \%$, from 1563 to $1429 \mathrm{~kg} \mathrm{ha}^{-1}$ (Table 4). Lower yields projected in the future climate scenario were partly due to greater fruit abscission.

For the Upland mid-season cotton cultivar grown under ambient climate and $\mathrm{CO}_{2}$ conditions, GOSSYM simulated $1563 \mathrm{~kg} \mathrm{ha}^{-1}$ of lint yield. Under the same climatic conditions, elevated $\left[\mathrm{CO}_{2}\right](540 \mathrm{ppm})$ resulted in a $10 \%$ increase in lint yield, from 1563 to $1713 \mathrm{~kg}$ $\mathrm{ha}^{-1}$. Simulation studies by Haskett et al. (1997) showed that soybean yield increased when climate change was simulated with increasing levels of $\left[\mathrm{CO}_{2}\right]$ similar to our observations. In a series of open-top chamber and free-air $\mathrm{CO}_{2}$ enrichment (from 550 to 650 ppm) experimental studies in Phoenix, Arizona, USA, Kimball \& Mauney (1993), Mauney et al. (1994) and Pinter et al. (1996) observed a 35 to $60 \%$ increase in yield with atmospheric $\mathrm{CO}_{2}$ enrichment under current weather conditions.

When all the projected climatic and atmospheric $\left[\mathrm{CO}_{2}\right]$ changes were included in the simulation, cotton yield decreased by $9 \%$, from $1563 \mathrm{~kg} \mathrm{ha}^{-1}$ (current climate scenario at $360 \mathrm{ppm} \mathrm{CO}_{2}$ ) to $1429 \mathrm{~kg} \mathrm{ha}^{-1}$ (FUT scenario at 540 ppm $\mathrm{CO}_{2}$ ) (Table 4). Similar results have been reported for rice (Olszyk et al. 1999, Sasseendran et al. 2000). In a series of temperature sensitivity experiments, Sasseendran et al. (2000) observed a $6 \%$ decrease in rice yield for every $1^{\circ} \mathrm{C}$ increment in temperature, and that yield decreased continuously for a positive change in temperature up to $5^{\circ} \mathrm{C}$. They also observed that the adverse temperature effects up to $2^{\circ} \mathrm{C}$ were offset by the beneficial $\mathrm{CO}_{2}$-enrichment effect at the 425 ppm level. The generally opposite effects of $\mathrm{CO}_{2}$ and temperature on rice yield were also observed in experimental and simulation studies of Olszyk et al. (1999). However, when an entire climate change scenario was taken into account (including beneficial $\mathrm{CO}_{2}$ and rainfall, and adverse temperature effects, projected in the future), rice yield
Future projections of crop yield generally depend on climate, location, crop type, and other environmental (e.g. soil type) and management factors.

Since developmental events occur more rapidly at higher temperature, the number of days to the appearance of the first-square, first flower and mature open boll decreases (Table 5). The projected temperature changes (TEMP scenario) caused the first open boll to occur $12 \mathrm{~d}$ earlier, first square $4 \mathrm{~d}$ earlier and flowering $7 \mathrm{~d}$ earlier compared to the current climate scenario. The faster development during the boll-filling period leads to smaller bolls in the future climates, resulting in lower yields in experimental studies (Hodges et al. 1993, Reddy et al. 2000). In addition to the positive correlation between temperature and development rates, Table 5 also shows that development rates are relatively independent of precipitation, solar radiation, and wind speed, as shown by identical DAE (days after emergence) values between the current and PPT, between the TEMP and TPPT, and between the TPPT and FUT climate scenarios.

Cotton under FUT had fewer fruits (squares and green bolls per plant) left on the plant at the end of the

Table 5. Average simulated dates of phenological events in cotton under various climate change scenarios at current $\left[\mathrm{CO}_{2}\right]$ of $360 \mathrm{ppm}$. FUT is with all climatic parameters modified and at $\left[\mathrm{CO}_{2}\right]$ of $540 \mathrm{ppm}$. DAE = days after emergence

\begin{tabular}{|c|c|c|c|c|c|c|}
\hline \multirow[t]{2}{*}{$\begin{array}{l}\text { Weather } \\
\text { scenarios }\end{array}$} & \multicolumn{2}{|c|}{$\begin{array}{c}\text { First } \\
\text { square }\end{array}$} & \multicolumn{2}{|c|}{$\begin{array}{c}\text { First } \\
\text { bloom }\end{array}$} & \multicolumn{2}{|c|}{$\begin{array}{c}\text { First } \\
\text { open boll }\end{array}$} \\
\hline & Date & DAE & Date & DAE & Date & DAE \\
\hline Current & $5 / 28$ & 28 & $6 / 19$ & 50 & $7 / 29$ & 90 \\
\hline TMAX & $5 / 26$ & 26 & $6 / 15$ & 46 & $7 / 22$ & 83 \\
\hline TMIN & $5 / 25$ & 25 & $6 / 14$ & 45 & $7 / 20$ & 81 \\
\hline TEMP & $5 / 24$ & 24 & $6 / 12$ & 43 & $7 / 17$ & 78 \\
\hline PPT & $5 / 28$ & 28 & $6 / 19$ & 50 & $7 / 29$ & 90 \\
\hline TPPT & $5 / 24$ & 24 & $6 / 12$ & 43 & $7 / 17$ & 78 \\
\hline FUT & $5 / 24$ & 24 & $6 / 12$ & 43 & $7 / 17$ & 78 \\
\hline
\end{tabular}




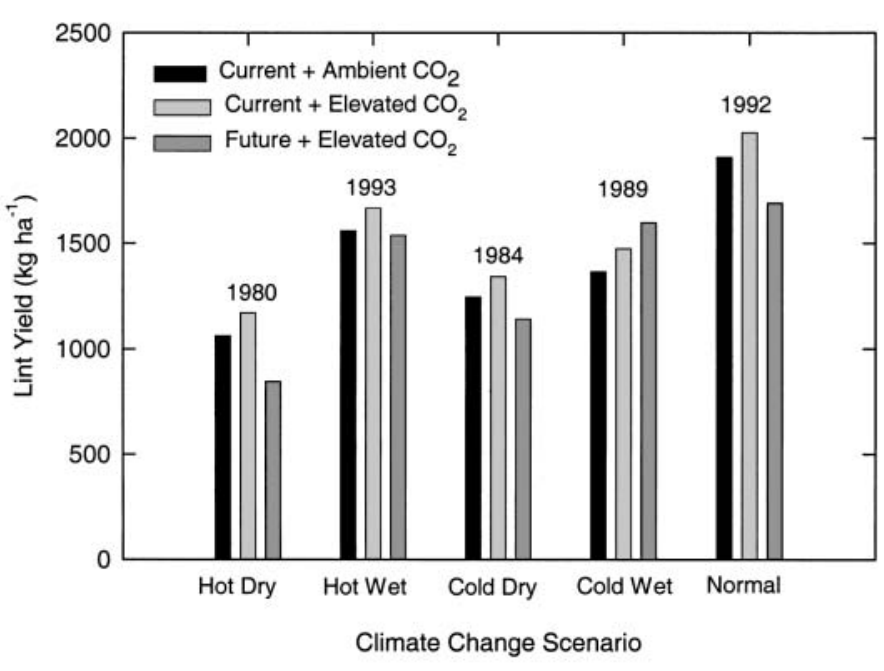

Fig. 4. Simulated cotton lint yield response to various weather patterns

season compared to under the current climate scenario. In the future climate scenario, the higher metabolic rate at higher temperatures (Fig. 2) combined with increased carbon availability causes more squares and flowers to be produced, but because of the adversities of weather not all the bolls are retained and mature. Lower yields were simulated in the future climate at higher temperatures during the fruiting period, because production efficiency (dry weight of bolls per total plant dry weight) declined rapidly above $29^{\circ} \mathrm{C}$ (Reddy et al. 1997a),

Under current climatic conditions, the high temperatures in many cotton-producing areas limit certain growth and developmental processes. Cotton might be planted earlier in future climatic conditions to avoid some of the hottest mid-summer temperatures during the reproductive periods (Reddy et al. 2000). Rosenzweig \& Hillel (1998) reported that irrigation and appropriate selection of planting dates could reduce the detrimental impacts of climate change. In addition, breeding for high temperature- and drought-tolerant cotton cultivars could alleviate adverse climate change effects on yield.

\subsection{Climatic extremes, and cotton growth and yield}

Climatic extreme conditions resulted in a trend similar to the 30-year average simulations except for a 'cold/wet' year. In general, years with extreme climatic events ('hot/dry'-1980, 'hot/wet'-1993, 'cold/dry'1984 and 'cold/wet'-1989) resulted in lower predicted yields compared with 'normal' year-1992. As might be expected, the effect of climate change on cotton production was most distinct in a 'hot/dry' year. However, in a 'cold/wet' year, climate change had a positive yield-response because the projected higher temperatures are still below the upper threshold temperatures for cotton (Fig. 4).

In a 'hot/dry' year (1980), the temperatures predicted for the Mississippi Delta are often above the upper threshold of $32^{\circ} \mathrm{C}$ for cotton fruit retention (Fig. 2). High temperature conditions cause flowers to abscise which removes carbon sinks and thus alleviates carbon stress. As a result, the crop continues to develop vegetative and reproductive growth, thus delaying the time of first open boll and maturity to later in the year when temperatures are conducive to fruit retention. During early vegetative growth stages, the rate of plant growth and development (plant height and node number) is higher in the future compared to the current climate scenario (Figs. 5 \& 6). Because of early induction of reproductive growth, plants grown in the future climate were subsequently shorter compared to those grown under current climate conditions. Reddy et al. (1997a) found that plants grown at 3,5 and $7^{\circ} \mathrm{C}$ above

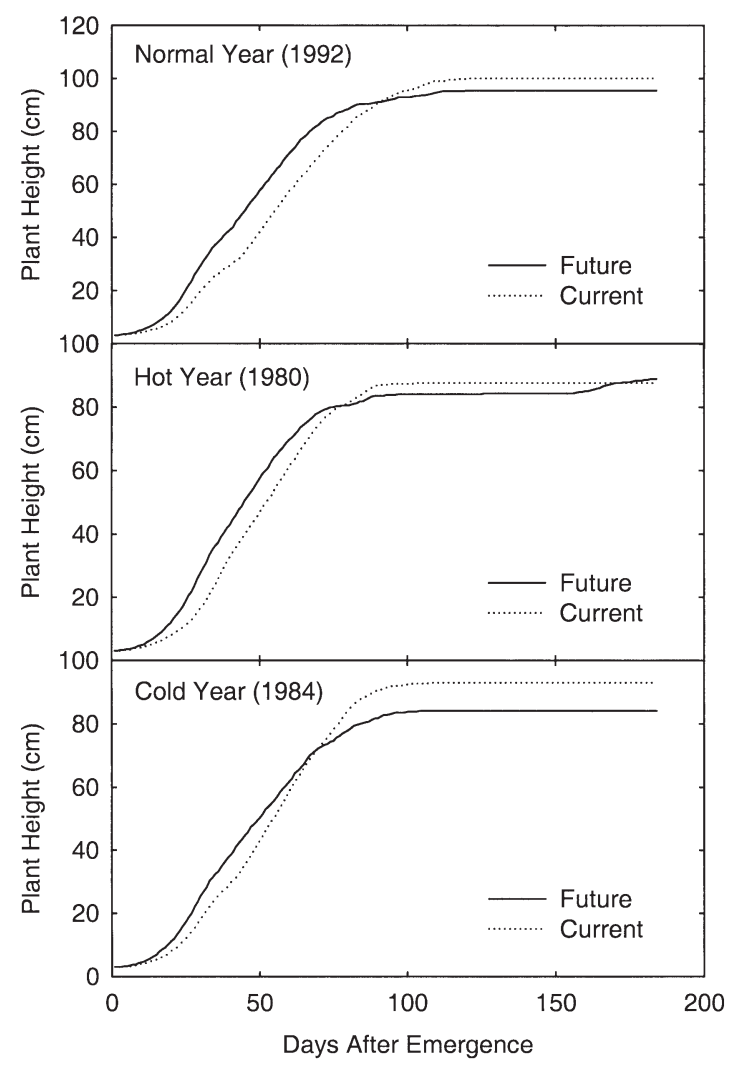

Fig. 5. Simulated plant height for years with different weather patterns, in the current and future climate scenarios 


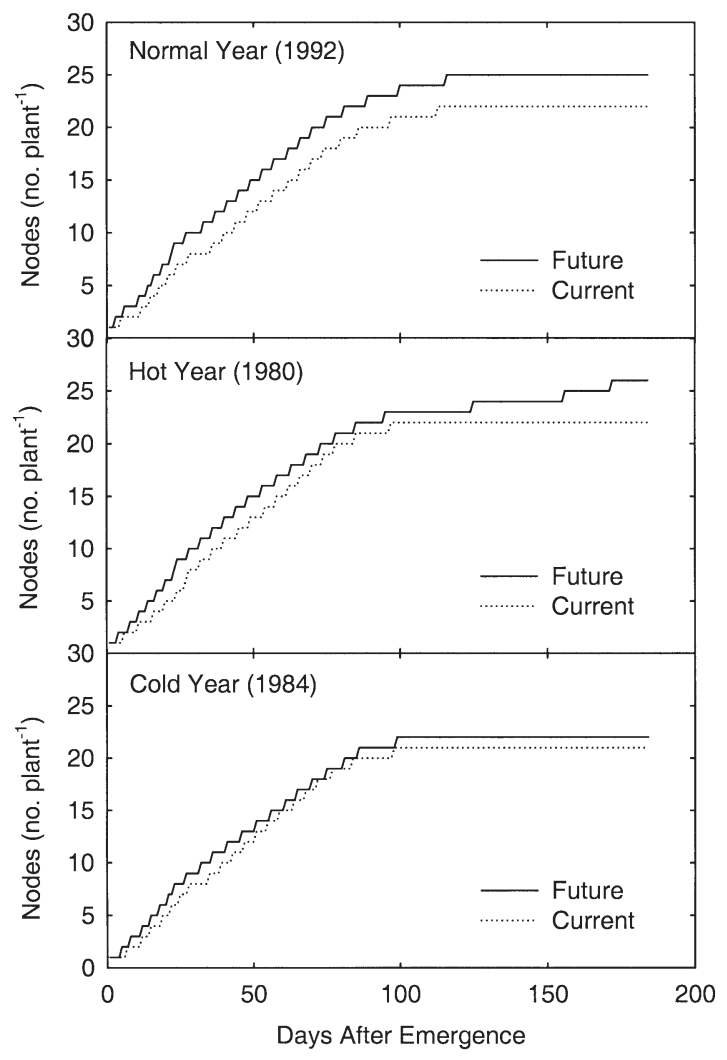

Fig. 6. Simulated node number on the plant for years with different weather patterns, in the current and future climate scenarios

ambient 1995 Mississippi temperatures flowered 3, 10 and $12 \mathrm{~d}$ earlier, respectively. Furthermore, their study showed that at $5^{\circ} \mathrm{C}$ higher temperature, early season growth (i.e. leaf area, plant height and dry weight of plants) was 6 to 8 times greater than at ambient temperature. Thus, higher temperatures would be advantageous during seedling establishment and early vegetative growth. Air temperatures between 45 and $55^{\circ} \mathrm{C}$ that occur for at least $30 \mathrm{~min}$, though not parameterized in GOSSYM, damage plant leaves in most environments; even lower temperatures $\left(35\right.$ to $\left.40^{\circ} \mathrm{C}\right)$ can be damaging if they persist longer (Fitter \& Hay 1987). Plant temperatures above $40^{\circ} \mathrm{C}$ are associated with stomatal closure and other high-temperature effects, which may be deleterious to cotton growth even under well-watered conditions. Temperatures above certain threshold levels for a few hours (wheat $>30^{\circ} \mathrm{C}$ for $8 \mathrm{~h}$, rice $>35^{\circ} \mathrm{C}$ for $1 \mathrm{~h}$, maize $36^{\circ} \mathrm{C}$ and cotton $40^{\circ} \mathrm{C}$ for $>6 h_{i}$ Acock \& Acock 1993) during anthesis results in lower fruit numbers, decreased biomass, and hence reduced economic yields. Only the damaging effects of average daily temperatures above $32^{\circ} \mathrm{C}$ on cotton fruit abscission are incorporated in the cotton model.

\section{SUMMARY AND CONCLUSIONS}

With continued increase of greenhouse gas emissions, crops in the future will be grown under higher atmospheric $\left[\mathrm{CO}_{2}\right]$ and probably higher temperature conditions than present. The projected climate change is expected to affect cotton production in the Mississippi Delta as represented by Stoneville, Mississippi. Although there was a $54 \%$ increase in simulated yields due to increased atmospheric $\left[\mathrm{CO}_{2}\right]$ from $200 \mathrm{ppm}$ to $900 \mathrm{ppm}$, the beneficial effects of higher atmospheric $\left[\mathrm{CO}_{2}\right]$ did not compensate for the adversities caused by projected changes in other climatic variables. An overall $9 \%$ decrease in cotton yield was obtained for the future climate. Nonetheless, yields were always higher under elevated $\mathrm{CO}_{2}$ compared with ambient atmospheric $\left[\mathrm{CO}_{2}\right]$ even under unfavorable climatic scenarios. Among the climatic variables, changes in projected temperature and rainfall most affected cotton production. High temperatures hastened development and shortened the growing period (days to maturity) by up to $11 \mathrm{~d}$ in the future climatic conditions. The enhanced metabolic rate at higher temperatures, combined with increased carbon availability (because of the effect of higher atmospheric $\left[\mathrm{CO}_{2}\right]$ on photosynthesis), caused more squares and flowers to be produced, but higher temperatures (greater than $29^{\circ} \mathrm{C}$ ) caused increased boll abscission. Thus, the climate change impact on simulated cotton production was adverse in 'hot/dry' years and was beneficial in 'cold/wet' years.

In the Mississippi Delta, cotton grown in a higher temperature environment in the future will need to be irrigated to satisfy the high water demand, although that issue was not included in this study. Irrigated crops have lower canopy temperatures that increase boll retention in above-optimum temperature environments. Cultural practices such as earlier planting to enhance yield, will undoubtedly evolve, but this will be limited by available radiation in non-summer periods. Many of the Upland cultivars do not tolerate the high temperatures projected, and the modern Pima cultivars are even more sensitive (Kittock et al. 1981, 1988, Reddy et al. 1992a,b, 1998b). As a result, strategies for reducing the impacts of climate change on cotton production should focus on developing heat-andcold- and drought-resistant cotton cultivars in order to mitigate the effects of climate change.

One of the shortcomings of this study is that the future climate scenarios were generated assuming the same natural daily variability in weather parameters as the present climate. This assumption arose from the nature of the future climate projection data generated by the RegCM, which provided only monthly mean estimates of future changes in weather parameters. Future research should conduct regional climate simu- 
lations to generate daily estimates, to capture changes in both the magnitudes and variabilities as a result of climate change. Incorporation of this daily-resolution input data into GOSSYM is expected to result in more realistic estimates.

With regard to parameters that cannot be tested in the field at present, a model must be conceptually sound, based on a sufficiently wide range of environmental conditions that include the extreme conditions anticipated in the future, and have been tested and found satisfactory where a broad array of practices, variable weather factors, and soils interact and impact on meaningful cultivars. Other unknowns and assumptions must be considered in addition; e.g. in this study the variability of weather factors in the future climate was assumed to not change, but climatic models are not sufficiently reliable to know whether or not this is a reasonable assumption.

Good science and judgment must prevail in order to avoid complications that may or may not exist. For example, pests (weeds, insects, diseases) or other factors may impact an experiment or validation study. Is the pest caused or influenced by the treatments being imposed? This cotton model was developed and validated without the impact of such a variable, and therefore, the model is not sensitive to interactions with such elements.

Acknowledgements. Appreciation is expressed for the excellent technical assistance provided by D. Brand, K. Gourley, W. Ladner and S. Turner. Part of this research was funded by the US DOE National Institute for Global Environment Change through the South Central Regional Center at Tulane University (DOE cooperative agreement no. DE-FCO3-90ER 61010) and the National Aeronautical and Space Administrationfunded Remote Sensing Technology Center at Mississippi State University (NASA grant no. NCC13-99001).

\section{LITERATURE CITED}

Acock B, Acock MC (1993) Modeling approaches for predicting crop ecosystem responses to climate change. In: Buxton DR, Shibles R, Forsberg RA, Blad BL, Asay KH, Paulsen GM, Wilson RF (eds) International crop science I. Crop Science Society of America, Madison, WI, p 41-55

Baker DN, Lambert JR, McKinion JM (1983) GOSSYM: a simulator of cotton crop growth and yield. South Carolina Agricultural Experiment Station Tech Bull 1089, Clemson

Boone MY, Porter DO, McKinion JM (1993) Calibration of GOSSYM: theory and practice. Comput Electron Agric 9: 193-203

Boone MYL, Porter DO, McKinion JM (1995) RHIZOS 1991: a simulator of row crop rhizospheres. USDA, ARS Bulletin 113, Government Printing Office, Washington, DC

Boykin DL, Carle RR, Ranney CD, Shanklin R (1995) Weather data summary for 1964-1993, Stoneville, Mississippi, USA, http://msa.ars.usda.gov/stoneville/ jwdsrc/wbook/ wbook.htm
Fitter AH, Hay RKM (1987) Environmental physiology of plants, 2nd edn. Academic Press, London

Gerik TT, Oosterhuis DM, Tolbert HA (1998) Managing cotton nitrogen supply. Adv Agron 64:115-147

Giorgi F, Mearns LO (1991) Approaches to regional climate change simulation: a review. Rev Geophys 29:191-216

Giorgi F, Marinucci MR, Bates GT (1993a) Development of a second generation regional climate model (RegCM2): Boundary layer and radiative transfer processes. Mon Weather Rev 121:2794-2813

Giorgi F, Marinucci MR, De Canio G, Bates GT (1993b) Development of a second generation regional climate model (RegCM2): convective processes and assimilation of lateral boundary conditions. Mon Weather Rev 121: $2814-2832$

Haskett JD, Pachepsky YA, Acock B (1997) Estimation of soybean yields at county and state levels using GLYCIM: a case study for Iowa. Agron J 87:926-931

Hodges HF, Reddy KR, McKinion JM, Reddy VR (1993) Temperature effects on cotton. Mississippi Agricultural and Forestry Experiment Station Bull 990, Mississippi State

Hodges HF, Whisler FD, Bridges SM, Reddy KR, McKinion JM (1998) Simulation in crop management: GOSSYM/ COMAX. In: Peart RM, Curry AB (eds) Agricultural systems modeling and simulation. Dekker, New York, $\mathrm{p}$ 235-281

Houghton JT, Meira Filho LG, Callander BA, Harris N, Kattenberg A, Maskell K (eds) (1996) Climate change 1995: the science of climate change. IPCC, Cambridge University Press, Cambridge

Houghton JT, Ding D, Griggs DJ, Noguer M, van der Linden PJ, Dai X, Maskell K, Johnson CA (eds) (2001) Climate Change 2001: the scientific basis. Contribution of Working Group I to the 3rd Assessment Report of the IPCC, Cambridge University Press, Cambridge

Jallas E (1998) Improved model-based decision support by modeling cotton variability and using evolutionary algorithms. PhD thesis, Mississippi State University, Mississippi State

Keeling CD, Whorf TP (1994) Atmospheric $\mathrm{CO}_{2}$ records from sites in the SIO air sampling network. In: Boden TA, Kaiser DP, Sepanski RJ, Stoss FW (eds) Trends '93: a compendium of data on global change. ORNL/CDIAC-65, Carbon Dioxide Information Analysis Center, Oak Ridge National Laboratory, Oak Ridge, TN, p 16-26

Khorsandi FK, Boone MYL, Weerakkody G, Whisler FD (1997) Validation of soil temperature subroutine HEAT in cotton simulation model GOSSYM. Agron J 89:415-420

Kimball BA (1983) Carbon dioxide and agricultural yield: an assemblage and analysis of 430 prior observations. Agron J 75:779-788

Kimball BA, Idso SB (1983) Increasing atmospheric $\mathrm{CO}_{2}$ : effects on crop yield, water use and climate. Agric Water Manag 7:55-72

Kimball BA, Mauney JR (1993) Response of cotton to varying $\mathrm{CO}_{2}$, irrigation, and nitrogen: yield and growth. Agron J 85:706-712

Kittock DL, Turcotte EL, Hofmann W C (1981) Fruiting of Upland and Pima cotton with different planting dates. Agron J 73:711-715

Kittock DL, Turcotte EL, Hofmann WC (1988) Estimation of heat tolerance improvements in recent American Pima cotton cultivars. Crop Sci 28:305-309

Mauney JR, Kimball BA, Pinter PJ Jr, LaMorte RL, Lewin KF, Nagy J, Hendry GR (1994) Growth and yield of cotton in response to free-air carbon dioxide enrichment (FACE) environment. Agric For Meteorol 70:49-68 
McGregor JJ (1997) Regional climate modeling. Meteorol Atmos Phys 63:105-117

McKinion JM, Baker DN, Whisler FD, Lambert JR (1989) Application of GOSSYM/COMAX system to cotton crop management. Agric Syst 31:55-65

Mearns LO (2000) The problem, changing biosphere: climatic change and variability. In: Reddy KR, Hodges HF (eds) Climate change and global crop productivity. CABI Publishing, Wallingford, UK, p 7-36

Mearns LO, Giorgi F, Shields C, McDaniel L (2002) Climate Scenarios for the Southeast US based on GCM and regional model simulations. Clim Change (in press)

Morison JIL (1987) Intercellular $\mathrm{CO}_{2}$ concentration and stomatal response to $\mathrm{CO}_{2}$. In: Zeiger $\mathrm{Z}$, Farquhar GD (eds) Stomatal function. Stanford University Press, Stanford, CA, p 229-251

Olszyk DM, Centeno HGS, Ziska LH, Kern JS, Mathews RB (1999) Global climate change, rice productivity and methane emissions: comparison of simulated and experimental results. Agric For Meterol 97:87-101

Pinter PJ Jr, Kimball BA, Wall GW, Hunsaker DJ, LaMorte RL (1996) Free-air $\mathrm{CO}_{2}$ enrichment: responses of cotton and wheat crops. In: Koch GW, Mooney HA (eds) Carbon dioxide and terrestrial ecosystems. Academic Press, San Diego, p 215-249

Reddy KR, Boone ML (2002) Modeling cotton leaf area development and stem elongation. Acta Hortic (Wageningen) (in press)

Reddy KR, Hodges HF, McKinion JM, Reddy VR (1992a) Temperature effects on early season cotton growth and development. Agron J 84:229-237

Reddy KR, Hodges HF, McKinion JM, Wall GW (1992b) Temperature effects on Pima cotton growth and development. Agron J 84:237-2243

Reddy KR, Boone ML, Reddy AR, Hodges HF, Turner S, McKinion JM (1995) Developing and validating a model for plant growth regulator. Agron J 87:1100-1105

Reddy KR, Hodges HF, McCarty WH, McKinion JM (1996) Weather and cotton growth: present and future. Mississippi Agricultural and Forestry Experiment Station Bull no. 1061, Mississippi State

Reddy KR, Hodges HF, McKinion JM (1997a) A comparison of scenarios for the effect of global climate change on cotton growth and yield. Aust J Plant Physiol 24:707-713

Reddy KR, Hodges HF, McKinion JM (1997b) Crop modeling and applications: a cotton example. Adv Agron 59: 225-290

Reddy KR, Hodges HF, McKinion JM (1997c) Water and nutrient deficits, crop yields and climate change. World Resour Rev 10:23-43

Reddy KR, Hodges HF, McKinion JM (1997d) Modeling temperature effects on cotton internode and leaf growth. Crop Sci 37:503-509

Reddy AR, Reddy KR, Hodges HF (1998a) Interactive effects of elevated carbon dioxide and growth temperature on photosynthesis in cotton leaves. Plant Growth Regul 22: $1-8$

Reddy KR, Robana RR, Hodges HF, Liu XJ, McKinion JM

Editorial responsibility: Robert Davis,

Charlottesville, Virginia, USA (1998b) Influence of atmospheric $\mathrm{CO}_{2}$ and temperature on cotton growth and leaf characteristics. Environ Exp Bot 39: $117-129$

Reddy KR, Davidonis G, Johnson A,Vinyard B (1999) Temperature regime and carbon dioxide enrichment alters cotton boll development and fiber properties. Agron J 91: 851-858

Reddy KR, Hodges HF, Kimball BA (2000) Crop ecosystem responses to climatic change: cotton. In: Reddy KR Hodges HF (eds) Climate change and global crop productivity. CABI Publishing, Wallingford, UK, p 161-187

Reddy KR, Kakani VG, McKinion, JM, Baker DN (2002) Applications of a cotton simulation model, GOSSYM/ COMAX, for crop management, economic and policy decisions. In: Ahuja LR, Liwang Ma, Howell TA (eds) Agricultural system models in field research and technology transfer. CRC, Boca Raton, FL, p 33-54

Reddy VR, Baker DN, Jenkins JN (1985) Validation of GOSSYM. Part II. Mississippi conditions. Agric Syst 17: 133-154

Reicosky DC, Hatfield JL, Sass RL (2000) The problem, changing biosphere: agricultural contributions to greenhouse gas emissions. In: Reddy KR, Hodges HF (eds) Climate change and global crop productivity. CABI Publishing, Wallingford, UK, p 37-56

Reilly JM, Schimmelpfennig D (1999) Agricultural impact assessment, vulnerability, and the scope for adaptation. Clim Change 43:745-788

Rosenzweig C, Hillel D (1998) Climate change and the global harvest. Oxford University Press, Oxford

Rosenzweig C, Iglesias A (1998) The use of crop models for international climate change impact assessment. In: Tsuji GY, Googenboom G, Thornton PK (eds) Understanding options for agricultural production. Kluwer, London, p 267-292

Rosenzweig C, Parry ML (1994) Potential impact of climate change on world food supply. Nature 367:133-138

Sassendran SA, Singh KK, Rathore LS, Singh SV, Sinha SK (2000) Effects of climate change on rice production in the tropical humid climate of Kerala, India. Clim Change 44: 495-514

Sequeira RA, Olson RL, Willers JL, McKinion JM (1994) Automating the parameterization of mathematical models using genetic algorithm. Comput Electron Agric 11: 265-290

Tubiello FN, Donatelli M, Rosenzweig C, Stockle CO (2000) Effects of climate change and elevated $\mathrm{CO} 2$ on cropping systems: model predictions at two Italian locations. Eur J Agron 13:179-189

USDA (1998) Agricultural statistics 1997. Government Printing Office, Washington, DC

Watterson IG (1998) An analysis of the global water cycle of present and doubled $\mathrm{CO}_{2}$ climates simulated by the CSIRO general circulation model. J Geophys Res 103: 23113-23129

Watterson IG, Dix MR, Colman RA (1999) A comparison of present and doubled $\mathrm{CO}_{2}$ climates and feedbacks simulated by three general circulation models. J Geophys Res 104:1943-1956

Submitted: November 2, 2001; Accepted: July 11, 2002 Proofs received from author(s): September 19, 2002 